\title{
LPG for Power Generation in Indonesia: Techno- economic and Distribution Analysis
}

\author{
Yussa Dony Antarius ${ }^{1 *}$, Rinaldy Dalimi ${ }^{2}$
}

\author{
${ }^{1}$ Department of Energy System Engineering, University of Indonesia \\ ${ }^{2}$ Department of Electrical Engineering, University of Indonesia \\ ${ }^{*}$ Corresponding author.Email: d_antarius@yahoo.com
}

\begin{abstract}
Application of LPG for power generation in Indonesia can be replacing the usage of fuel-oil at the existing power plant. It turns out that LPG is also a flexible and low-emission alternative to other fuel types within power generation that equal with other natural gas such as LNG or CNG. The main LPG advantages are the distribution which very well developed in Indonesia, handling LPG is also cheaper and saver since it does not have to be transported in cryogenic temperatures like in the case of LNG, neither high pressurized tank in the case of CNG terminal. Therefore, LPG might be a good solution for gasification program for the fuel-oil-driven power plants, which currently facing obstacles in the high cost of LNG regasification infrastructure, whereas this is a major concern in a long term investment in the power industry. This paper presents a techno-economy and distribution analysis start with the analysis matrix of how feasible a power plant to be converted to LPG until the calculation of capital expenditure, operation expenditure includes the distribution cost and distribution clustering scheme for the LPG supply chain. The existing power plants were divided into 13 clusters, where the study found 5 clusters are very competitive with the energy price less than 4 USD/MMBTU, 4 clusters are average competitive with the energy price between 4 to 6 USD/MMBTU, and 4 other clusters are not competitive with the energy price more than 6 USD/MMBTU.
\end{abstract}

Keywords - LPG power generation, Energy System Saving, LPG/ LNG Price.

\section{INTRODUCTION}

\subsection{Energy Transition}

In accordance with the mandate of the National Energy Policy [1], which is to minimize the use of the portion of petroleum, optimize the use of natural gas, maximize renewable energy, and convert coal into energy reserves, the Indonesian government is currently committed to accelerating the gasification program on electricity generation. This program is at the same time to reduce carbon emissions and other greenhouse gases according to the Kyoto Protocol [2].

The commitment of the Government of Indonesia in accordance with the National Energy Policy (KEN), namely to minimize the use of fuel oil and optimize the use of natural gas, was implemented by the government through the Minister of Energy and Mineral Resources by issuing a decree of the Minister of Energy and Mineral Resources No. 13/2020 concerning Determining the Implementation of Supply and Development of LNG Infrastructure, and Conversion of the Use of Fuel-Oil (BBM) with LNG in the Provision of Electric Power. The LNG gasification program which is prioritized for gas power plants - which is currently driven using fuel oil (diesel) - faces obstacles in the high cost of LNG regasification terminal infrastructure. This is a major concern in the calculation of the electricity industry's long-term investment.

The gasification program is also to accelerate the distribution of power plants for even distribution of electricity - especially on small islands - filled with the government using oil-fired power plants because the supporting infrastructure for LNG distribution and storage is limited and expensive. The power plant gasification program launched by the government 
currently faces obstacles in the high cost of LNG terminal infrastructure. Whereas in Indonesia, fuel oil contributes to produce $16 \%$ of total electricity production, but the cost reaches $53.8 \%$ of the total fuel cost [3]. Power plants, especially Gas Turbines and Gas Engines whose original design uses natural gas, are operated with expensive fuel oil, resulting in lower engine efficiency and also resulting in higher carbon emissions.

\subsection{LPG as Primary Energy}

Worldwide, the consumption of LPG amounted to 317 million tons in 2019 [4]. The residential sector is by far the biggest user, accounting for $43.5 \%$ of all the LPG used [4]. Petrochemicals are the second-largest consuming sector, accounting for a quarter of total world LPG consumption. The transport and industrial sectors absorb the rest. LPG is used in all the major sectors,

\subsubsection{Residential Sector}

LPG is well suited for cooking, and space and water heating. In some developing countries, it is also used for lighting where electricity is not available. In developed countries, it may be used for outdoor activities such as barbecues and camping.

\subsubsection{Agriculture}

LPG is used to increase the production and the quality of farm products through weed flaming crop harvesting, and crop drying. It is also used to heat breeding houses for pigs and poultry and power farm equipment such as irrigation pump engines.

\subsubsection{Commercial sector}

Applications include commercial cooking (restaurants and small and large-scale catering), and water and space heating in offices and other commercial premises.

\subsubsection{Industry}

LPG is used in a wide range of industrial processes and activities, notably where a high degree of precision and flexibility in process temperatures - as well as a strong flame - are required. Common applications include heat treatment furnaces, direct firing of ceramic kilns, glass working, textile and paper processing, and paint drying.

\subsubsection{Power Generation}

LPG can also be used as back-up fuel for electricity generators, including hybrid renewable energy systems in remote locations. In 2014 the first LPG power plant was operated, it was fully supported by the engine and turbine manufacturer that made their product readily available to fueled by LPG.

\subsubsection{Transport}

LPG is increasingly used as a low-emission alternative to gasoline and diesel for taxis, buses, and private cars.

\subsubsection{Petrochemical Industry}

LPG is used as an alternative to ethane, naphtha and middle distillates in the production of ethylene, the main bulk petrochemical intermediate product used in the manufacturing of a wide range of plastics and specialty chemicals.

\subsection{Ideal Market for LPG Power Generation}

By identifying the market characteristics which make a market ideal for LPG power generation, it is the intention that this will allow the LPG industry to:

- Develop a framework for identifying the most promising potential markets for LPG power generation.

- Identify the top prospect markets for LPG power generation.

- Develop a strategy for targeting these identified locations.

It should be noted that a market does not need to have all of the characteristics which are described throughout this study (and in any case, there is unlikely to be any place which meets all of the listed criteria). Instead, the characteristics should be considered as a 'wish list' which outlines the desirable features of a market which is ideal for LPG power generation.

\section{MATERIAL AND METHODS}

\subsection{Market Outlook}

The current market outlook for LPG power generation in Indonesia:

- High diesel prices, reduction in subsidies for diesel since Indonesia highly rely on fuel oil for power 
generation, especially in scattered small islands in East Indonesia. The fuel-oil cost more than half of the total fuel cost in the electricity generation makes a good opportunity for LPG as a fuel alternative.

- Growing electricity demand and plans to incentivize and accelerate deployment of generation capacity specially to fill short-term power gaps in remote regions with no natural gas infrastructure, could support LPG Power Generation deployment in the near term.

- Instead, the expansion of the natural gas grid will make it tough for LPG Power Generation in the long term.

High diesel prices with weakening policy support for diesel presents a good opportunity for LPG. Currently a high share of coal in the power generation mix results in low electricity prices of USD $0.09 / \mathrm{kWh}$ in Indonesia [4]. Competing with this will be difficult for LPG, but where power generation still powered by expensive fuel oil, which currently used at around 5,000 gensets across the country [4], LPG presents a more economically attractive option.

There is a good opportunity for LPG to replace, or to compete, with new generation plants with less carbon emissions. A strong drive from Government to extend the natural gas grid could result in this window of opportunity being limited, but natural gas will likely be targeted at displacing coal fired generation first, which accounts for over $50 \%$ of electricity generation.

A growing economy and growing energy demands put further pressure on an already weak electricity grid, which currently covering $80 \%$ of the country. The Indonesian archipelago currently suffers from lengthy blackouts - spurring the need for distributed electricity power. The Government of Indonesia estimates that electricity demand will likely rise by $4-5 \%$ per annum, resulting in the rising need of additional power generation, especially in remote areas, and extension of the electricity grid coverage as well.

The current government plans to improve the natural gas grid and increase gas supplies, with $50 \%$ of all gas produced to be used locally. The main gas demand centres in Java and Sumatera, are experiencing gas supply deficits, which could take over than ten years to rectify.

The Government of Indonesia policy focus is on energy supply security, which involves power plant construction incentive and the use of local resources. Combined with the likely reduction in subsides for diesel, this could make LPG Power Generation an attractive option.

The LPG power plant Analysis Methods covering two major parameters as follows,

\subsection{Technology}

Gas Engine / Gas Turbine with LPG. Technically there is no issue to use LPG to fuel Gas Engine. The LPG must be put into a certain condition such as must be in the gas form and the pressurized. For some engine manufacturer that designing the dual fuel engine, there is no special adjustment needed during the fuel changeover and can be performed with the engine running. [6]

Diesel engine with LPG, different from the gas engine, to do the LPG conversion, the diesel engine will need a few modifications and adjustments. There are currently two ways of using LPG as a fuel for a Diesel engine:

- Spark-ignition addition on the combustion chamber.

- $\quad$ LPG Mixing with fuel-oil (diesel) before sprayed into the combustion chamber.

\subsection{Potential Site Selection}

To determine if a power plant feasible to be converted to gas, it is separated into 4 (four) different priority criteria as follows,

- Criteria 1 - Potential for gas conversion, gas supply not define yet, no gas sources nearby, and near from logistic supply route.

- Criteria 2 - Potential for gas conversion, gas supply not define yet, no gas sources nearby, but far from logistic supply route.

- Criteria 3 - Not potential for gas conversion, since gas supply has been defined.

- Criteria 4 - Not potential for gas conversion, since power plant has been supplied/ will be soon supplied by gas, nor the power plant will be soon replaced by the other technology.

From the available market, only power plant with priority criteria 1 and 2 are feasible for the gasification simulation at the next phase. The result of selection shows in table below. 


\begin{tabular}{lcc} 
TABLE 1. & \multicolumn{2}{c}{ Available Power Plant [10] } \\
\hline $\begin{array}{l}\text { Power } \\
\text { Plant }\end{array}$ & $\begin{array}{c}\text { Available } \\
\text { Market } \\
{[\mathbf{M W}]}\end{array}$ & $\begin{array}{c}\text { Potential } \\
\text { Market } \\
{[\mathbf{M W}]}\end{array}$ \\
\hline PLTD & 3.978 & 1.392 \\
PLTG & 3.071 & 1.490 \\
PLTMG & 3.894 & 2.098 \\
PLTGU & 20.994 & 1.500 \\
\hline & 31.936 & 6.480 \\
\hline
\end{tabular}

At this stage, the simulation of LPG distribution at a potential power plant is carried out at the power plant with priority 1 . The plants are grouped according to the distribution path simulation into 13 clusters as follows,

- Cluster 1: Bangka, Belitung, West Kalimantan

- Cluster 2: West Sumatera, Nias

- Cluster 3: Bontang, North Sulawesi

- Cluster 4: Bontang, Central Sulawesi

- Cluster 5: Kotabaru, West Sulawesi

- Cluster 6: South Sulawesi, South East Sulawesi

- Cluster 7: West Nusa Tenggara

- Cluster 8: East Nusa Tenggara

- Cluster 9: Gorontalo, Central Sulawesi

- Cluster 10: Ternate, Halmahera

- Cluster 11: Maluku

- Cluster 12: Papua

- Cluster 13: Papua Barat

\section{RESULT}

To define which cluster is feasible for further supply by LPG, the LCOE will be divided into 3 (three) cost categories:

- Competitive: <4 USD/MMBTU

- Average: 4-6 USD/MMBTU

- Not-competitive: >6 USD/MMBTU

Power generation clusters that are competitive for LPG-fueled are clusters that have a LCOE of under 6 USD / MMBTU. From 13 LPG distribution clusters, the study found that,
- Competitive cluster: Cluster 1, Cluster 4, Cluster 6, Cluster 7, Cluster 9.

- Average cluster: Cluster 2, Cluster 8, Cluster 10, Cluster 12: are average.

- Not competitive cluster: Cluster 3, Cluster 5, Cluster 11, Cluster 13.

\section{DISCUSSION}

\subsection{Financial Calculation}

The method of finding the right price is testing the LPG Levelized Cost of Electricity price to earn the assumed profitable and conservative IRR value. In this financial model, the profitable and conservative IRR value to be used is around $16 \%$. Therefore, the LPG mid-stream price should be adjusted based on the same financial model in each cluster with each operational assumption in the cluster.

The Capital Asset Pricing Model (CAPM) will be used to calculate the discount rate. This method will provide the weighted average cost of capital (WACC) as the discount rate.

WACC $=($ Proportion of Equity $x$ Cost of Equity $)$

+ (Proportion of Debt $x$ Cost of Debt)

The value of WACC will be a reference to the calculation of the financial feasibility. The financial feasibility indicator that is shown with the Internal Rate of Return (IRR) value should be higher than this WACC value. The higher the value differences of IRR than WACC, the more feasible that the project could be executed. Also, the business model should have a Minimum Acceptable Rate of Return (MARR) of the minimum IRR that should be accepted. The MARR value also should be higher than the discount rate (WACC).

The financial projection that will be applied to all of the segments is a 20-year time-period. Thus, the LPG supply business model is expected to exist in 20 years. The assumption of the investment proportion is $30 \%$ equity and $70 \%$ debt. Therefore, there will be a calculation of interest payment in the financial projection, with a grace period of 12 months and Interest During Construction (IDC) will be in the first year. The estimated IDC will be funded outside the investment fund, and also working capital is assumed to be fulfilled by $100 \%$ of investor's funding. 
One of the purposes of this report is to find the feasible price and profitable business model by estimating the right LPG mid-stream price. The method of finding the right price is testing the LPG mid-stream price to earning the assumed profitable and conservative IRR value. This financial modeling calculates midstream price of each distribution cluster. The calculation simulation (in USD) includes the following cost component:

- Capital expenditures;

- Revenue projection;

- Operational expenditures;

- Income statement;

- Cash flow;

- LPG storage;

- Regasification unit cost;

- Pipeline cost;

- Gas metering cost;

- Berthing jetty cost;

- Port facility cost;

- Ship charter cost \& fuel cost;

- Overpriced factor (correction factor).

\section{CONCLUSION}

From the study, there are some conclusions as listed below,

- There are $70 \%$ of the cluster found competitive in the current market where the study has been made.

- The higher of total MW and the least of the investment cost of each cluster will result in the cheaper electric price.

- Using LPG, the electric price can be more competitive as a good alternative solution to replace the fuel-oil.

- Since the shale gas was commercially mined and the price of LPG are declining, the price of electricity from LPG will be more competitive.

\section{ACKNOWLEDGMENTS}

This research was supported by University of Indonesia (UI) through PUTI Proceeding grant 2020 launched by DRPM UI.

\section{REFERENCES}

[1] Arifin Z, "Konsumsi BBM Untuk Pembangkit Listrik Di Indonesia", Researchgate, Publication 337672003, 2015.

[2] Berry Sg, Betterton Ce, Karagiannidis I, "Understanding Weighted Average Cost of Capital: A Pedagogical Application", Researchgate, Publication 289530651, 2014.

[3] Kuba S, Lare R, Asai T, Kamino K, "Lpg Burning Gas Turbine Technology", Mitsubishi Hitachi Power Systems, Ltd, 2016.

[4] Pemerintah Republik Indonesia, "PP No.79 Tahun 2014 Tentang Kebijakan Energi Nasional”, ESDM, 2014.

[5] Pemerintah Republik Indonesia, "UU No.17 Tahun 2004 Tentang Pengesahan Protokol Kyoto Atas Konvensi Kerangka Kerja Perserikatan BangsaBangsa Tentang Perubahan Iklim”, Esdm, 2004.

[6] PT. Perusahaan Listrik Negara (Persero), "Rencana Usaha Penyediaan Tenaga Listrik PT. PLN (Persero) 2019-2028”, PLN, 2019.

[7] World LPG Association, "Annual Report 2019”, WPLGA, 2019.

[8] World LPG Association, "Global LPG Power Generation - Market Development \& Recommendations for Future Growth", WLPGA, 2019.

[9] Dewan Energi Nasional, Indonesia Energy Outlook 2019, ESDM, 2019.

[10] PT. Perusahaan Listrik Negara (Persero), "Laporan Tahunan 2019”, PLN, 2019. 